\title{
Compliance Costs of Transfer Pricing in Case of SMEs: Czech Case
}

\author{
Veronika Solilová - Danuše Nerudová \\ - Hana Bohušová - Patrik Svoboda ${ }^{*}$
}

\begin{abstract}
:
Small and medium sized enterprises account for over $99 \%$ of all companies in European Union and have very important position in the EU economy in the area of growth and employment. However, they face great deal of obstacles, such as compliance costs of taxation, 28 different tax systems in Europe, difficult transfer pricing rules and so on. Further, compliance costs of taxation are regressive with regard to firm size and significantly higher in case of enterprises with foreign branch or subsidiary in comparison with enterprises which are not internationalized. Moreover, compliance costs are increasing through strict and difficult transfer pricing rules among European countries. Therefore, taxes and new obligations should be carefully designed so that they can address the disproportionately high tax compliance burdens faced by those enterprises. Unfortunately, there does not exist a study determining compliance costs of transfer pricing issue in the literature. Therefore, the aim of paper is to determine compliance costs of transfer pricing issues in case of SMEs. The results are based on the questionnaire distributed among Czech parent companies having subsidiaries in Europe and Czech subsidiaries having a parent company in Europe. Based on the results we can conclude that costs for managing of transfer pricing requirements can reach from EUR 6,430 to 7,704 per year, time needed for this issue between 27 and 35 working days and in case of comparison with corporate tax collection it represents between $3.90 \%$ and $12.74 \%$.
\end{abstract}

Key words: Small and medium sized enterprises; Transfer pricing rules; Compliance costs.

JEL classification: M1, H26, F23, G38.

\footnotetext{
Veronika Solilová; Mendel University Faculty of Business and Economics, Department of Accounting and Taxation, Zemedelska 1, 61300 Brno, Czech Republic, <ritve@email.cz>.

Danuše Nerudová; Mendel University, Faculty of Business and Economics, Department of Accounting and Taxation, Zemedelska 1, 61300 Brno, Czech Republic, <d.nerudova@ seznam.cz>. Hana Bohušová; Mendel University, Faculty of Business and Economics, Department of Accounting and Taxation, Zemedelska 1, 61300 Brno, Czech Republic, <hana.bohusova@ mendelu.cz>.

Patrik Svoboda; Mendel University, Faculty of Business and Economics, Department of Accounting and Taxation, Zemedelska 1, 61300 Brno, Czech Republic, <patrik.svoboda@mendelu.cz>.

The article is processed as an output of a research project „Small and medium size enterprises in global competition: Development of specific transfer pricing methodology reflecting their specificities" registered by the Grant Agency under the registration number 15-24867S.
} 
Solilová, V. - Nerudová, D. - Bohušová, H. - Svoboda, P.: Compliance Costs of Transfer Pricing in Case of SMEs: Czech Case.

\section{Introduction}

In European Union, the European Commission (2003) provides the commonlyused categorization of small and medium-sized enterprises (hereinafter SMEs) which is based on the number of employees and their turnover or balance sheet total. Based on it, the SMEs are categorized on micro ${ }^{1}$, small $^{2}$ and medium-sized ${ }^{3}$ enterprises. Altogether SMEs account for over $99 \%$ of all companies in EU, which contribute both a considerable proportion of value-added (i.e. almost 58\%) and to total employment (i.e. almost 90 mil jobs) as states European Commission (2015). In comparison with SMEs, large enterprises (hereinafter LEs), which account for almost 44 th. companies in EU, generate $33 \%$ of value-added and provide more than 44 mil jobs. It is obvious, that LEs use effectively all resources, mainly due to the economies of scale (for more details see table 1).

Tab. 1 Summary of SMEs and large enterprises in the EU28 in 2014

\begin{tabular}{lllllll}
\hline & Micro & Small & $\begin{array}{l}\text { Medium } \\
\text { sized }\end{array}$ & SMEs & Large & Total \\
\hline $\begin{array}{l}\text { Enterprises } \\
\text { (Number) }\end{array}$ & $20,710,324$ & $1,373,365$ & 224,811 & $22,308,500$ & 43,766 & $22,352,260$ \\
\% & 92.7 & 6.1 & 1.0 & 99.8 & 0.2 & 100 \\
$\begin{array}{l}\text { Persons } \\
\text { Employed } \\
\text { (Number) }\end{array}$ & $39,274,088$ & $27,452,716$ & $23,257,412$ & $89,984,216$ & $44,438,724$ & $134,422,944$ \\
\% & 29.2 & 20.4 & 17.3 & 66.9 & 33.1 & 100 \\
$\begin{array}{l}\text { Value Added } \\
\text { (EUR billion) }\end{array}$ & 1,358 & 1,169 & 1,188 & 3,715 & 2,710 & 6,425 \\
\% & & 18.2 & 18.5 & 57.8 & 42.2 & 100 \\
\hline Source: Annua & 21.1 & report & & & & \\
\hline
\end{tabular}

Source: Annual report on European SMEs 2014/2015, European Commission 2015.

1 Microenterprises are defined as a firm with less than 10 employees and a balance sheet or turnover below EUR 2 million.

2 Small enterprises are defined as enterprises having less than 50 employees and turnover or balance sheet total of less than EUR 10 million.

3 Medium-sized enterprises are defined as enterprises which employ fewer than 250 persons and which have an annual turnover not exceeding EUR 50 million, and/or an annual balance sheet total not exceeding EUR 43 million. 
Moreover, SMEs are usually less well-equipped than LEs with financial and human resources. Therefore, they usually cannot use benefits resulting from tax planning strategies and the application of tax planning's instruments. One of the tax planning instruments is transfer pricing which helps to reduce tax risks and overall tax liability. In this respect, the OECD estimates annual losses from 4-10\% of global corporate income tax revenues, i.e. USD 100 to 240 billion annually. To avoid this practice and ensure the correct application of the separate entity approach, the OECD and G20 countries launched a project on Base Erosion and Profit Shifting (hereinafter as BEPS) in February 2013, which includes 15 Action plans referring to tax planning strategies, shifting profits to low or no-tax locations resulting in little or no overall corporate tax being paid. The final reports of the project were published on 5 October 2015.

To avoid divergent implementation of BEPS by each EU Member States and disruption of the functioning of the internal market, the European Commission published the draft of the Directive "laying down rules against tax avoidance practices that directly affect the functioning of the internal market", known as the Anti Avoidance Directive, on 28 January 2016. The draft of the Directive should create a minimum protection for all Member States' corporate tax systems by transpose the OECD BEPS measures into their national systems in a coherent and coordinated fashion.

It is obvious that both published documents and their implementation will have significant effects on the enterprises and their corporate tax liability. However, currently SMEs face a lot of disadvantages due to their size which can have distortive impacts on commercial decisions, business forms and business activities. The disproportionately high impact of regulatory requirements also creates the disproportionately high compliance costs of taxation, which have a regressive character with regard to firm size (Cordova-Novion and De Young, 2001, Slemrod, 2006, Shaw et al., 2008, Obermair et al., 2008 and others). Further, OECD stated that compliance cost of taxation in case of SMEs represent $46 \%$ of incurred costs (OECD, 2001). Moreover, (Slemrod, 2006) adds that compliance costs of taxation usually depend, inter alia, on size (in a regressive way), sector, and multinationality. Therefore, taxation and other obligations should be carefully designed so that they can address the disproportionately high tax compliance burdens faced by SMEs.

The aim of paper is to determine compliance costs of transfer pricing issues in case of SMEs having tax residence in the Czech Republic (i.e. Czech parent companies having subsidiaries in Europe and Czech subsidiaries having a parent company in Europe) based on data collection through a questionnaire. 
Solilová, V. - Nerudová, D. - Bohušová, H. - Svoboda, P.: Compliance Costs of Transfer Pricing in Case of SMEs: Czech Case.

\section{Theoretical Background}

\subsection{Transfer pricing issue}

The concept of using transfer pricing and its arm's length principle (hereinafter standard) for taxation purposes can be originated in 1932 when the first tax treaty ${ }^{4}$ was signed that included an allocation norm for business income among associated enterprises in the form of the arm's length principle, as stated by Solilova and Steindl (2013). Further, the arm's length principle was recommended as a suitable allocation norm in Caroll Report (Caroll, 1933). Until the first OECD Model Convention in 1963, the classification of article dealing with the arm's length principle was several times changed, but into the first OECD Model Convention was included as Art. 9(1) based on the London Model from 1946. However, as mention Solilova and Steindl (2013), the current form of the standard was added to the OECD Model Convention in 1977 during its first revision.

Under this standard, associated entities must set transfer pricing for any intercompany transaction as if they were unrelated entities and all other aspects of the relationship were unchanged. Applying and testing the arm's length principle requires a deep understanding of the circumstances - i.e. the commercial and financial relationships, in which associated enterprises make transactions and agree on their transaction prices, and should reflect the economic reality of how enterprises works. However, there is some evidence, that the standard does not reflect both economic reality and whether the third party would enter into the transaction, but it is rather proved the income shifting between enterprises as state Keuschinigg and Devereux (2013), Taylor, Richardson and Lanis, (2015), Bartelsman and Beetsma (2000), Well and Lowell (2014), Hines and Rice (1994) and Huizinga and Laeven (2006). It fully corresponds with the fact, that the transfer pricing represents an instrument which is used as tax planning tool, i.e. properly chosen transfer pricing strategies can enable the distribution of the tax risks and profits resulting in the reduction of the overall tax liability as state Buus (2009), Solilová and Nerudová (2012, 2013), Swenson (2001) and Rojiček (2012). To avoid this practice and to ensure the correct application of the separate entity approach and the standard, the BEPS project was launched and consequently the draft of Anti Avoidance Directive was published in EU.

As regards as transfer pricing issue, only two deliverables of BEPS project are focusing on it, particularly the Action plan 8-10 "Aligning Transfer Pricing Outcomes with Value Creation" and the Action plan 13 "Guidance on Transfer Pricing Documentation and Country-by-Country Reporting. Based on the Action Plan 13, all enterprises are required to report information relating to their economic activity such as revenues, profits, taxes paid and certain measures of economic

4 The arm's length principle was implemented in the U.S-France treaty 1932 for the first time. 
activity, and to articulate their consistent transfer pricing positions through this standardized approach of reporting. So, new reporting obligation is required to the current transfer pricing documentation. Based on the Action plan 8-10, in the area of transfer pricing analysis and determination of transfer prices, a correct application of the standard demands an understanding of the value drivers and relevant risks involved and how responsibility for those risks is attributed among the associated enterprises in the context of their commitment to creating value jointly. For the level and assumption of risk are economically relevant characteristics that can be significant in determining the outcome of a transfer pricing analysis. The understanding of the risks is therefore crucial. Currently, the OECD Transfer Pricing Guidelines for Multinational Enterprises and Tax Administrations (1995, 2010) (hereinafter as TP Guidelines) state five economically relevant comparability factors - i.e. characteristics of property transferred or services provided, functional analysis, contractual terms of the transaction, economics circumstances of the parties and of the market in which the parties operate, and business strategies, which were further supplemented by a nine-step process of comparability analysis resulting in the accepted good practice of applying the recommendations of the revised Guidelines in 2010.

On one hand, Pris et al. (2014) state that functions, assets and risks are not systematically aligned in a clear and easily defined pattern of entities and locations, thus the concept of the current comparability analysis can lead to incorrect inferences about non-compliant behaviour. Therefore, the recommendation of BEPS highlights based on the value creation that the understanding risks and mapping the responsibilities of the individual associated enterprises for the different risk categories through accurately delineating functional analysis, can help to fully assess the respective contributions by these enterprises to the joint value creation and derive the relative bargaining position of each of them. The bargaining power is essential for drawing conclusion as to whether third parties would enter, or would have entered, into the transactions at the prevailing terms and conditions, and for the conclusion whether the transactions are "at arm's length". On the other hand Lohse and Riedel (2013), Wells and Lowell (2014) add that, there is some evidence that is critical to the BEPS recommendations and its solution in respect of the elimination of profit shifting and correct application of the standard. They further highlight that problems with transfer pricing are mainly rooted in the longstanding TP Guidelines and the statement of the standard in the OECD Model Convention. The possible solution can be found in the modification of these documents rather than in more complex of transfer pricing documentation and transparency resulting in higher compliance costs of taxation. 
Solilová, V. - Nerudová, D. - Bohušová, H. - Svoboda, P.: Compliance Costs of Transfer Pricing in Case of SMEs: Czech Case.

\subsection{Compliance costs of taxation}

From the current point of view, the compliance costs were defined by Sandford (1995) as the burden imposed upon taxpayer as a result of their taxation obligation. Accordingly, to this definition, a lot of international comparative studies can be found in literature. Globally, four major findings on compliance costs of taxation should be highlighted there. Firstly, compliance costs are significant and high. Based on the OECD survey, it represents $46 \%$ of incurred costs in case of SMEs (OECD, 2001). Secondly, compliance costs are regressive i.e. SMEs face the disproportionately high compliance costs of taxation than LEs (Slemrod, 2006, Shaw et al., 2008, Obermair et al., 2008, Cordova-Novion and De Young, 2001, Chittenden et al., 2000 and others). Thirdly, compliance costs are not reducing over time (Obermair et al., 2008). Finally, compliance costs of taxation usually depend, in alia, on size, sector and multinationality (Slemrod, 2006). Chittenden et al. (2000) adds that SMEs bear hundred times higher compliance costs of taxation than LEs.

Further, compliance costs represent one of tools for the measuring of complexity of tax system, whose measurement is problematic in the area of economy as state Pavel et al. (2015). It is mainly due to the above mentioned reasons, further due to the fact, that compliance costs can support tax evasion/avoidance and increase for business active across borders, i.e. are significantly higher in case of enterprises with foreign branch or subsidiary in comparison with enterprises which are not internationalized as stated Nerudová et al. (2009) and Cressy (2000), and due to the fact, that compliance costs represent inefficient use of scarce resources in the economy.

In respect of drivers for compliance costs of taxation, KPMG (1996 and 2006), Evans (2003) and Green (1994) identified significant drivers in the form of changes of tax system or taxes and complexity of tax system or tax regulation. Shaw et al. (2008) add that lower compliance costs of taxation are usually in countries, where the tax or tax system is simple. Therefore, tax policymakers should decide between complexity and simplicity, and between a more frequent change or more consultative change.

In respect of compliance costs of transfer pricing, current literature does not cover studies measuring those compliance costs. Transfer pricing issue is covered into the area of corporate taxation. Based on it, it is assumed that those compliance costs are also covered together with compliance costs of corporate taxation. The compliance costs of corporate taxation in case of the Czech Republic were determined by Vítek et al. (2008) in the amount of $5.5 \%$ and by Pudil et al. (2004) in the amount of $5.3 \%$ as a portion of compliance costs to corporate tax collection. European Commission recognizes that high compliance costs in the field of transfer pricing can negatively affect the Internal Market, therefore the EU Transfer 
Pricing Forum developed EU Transfer Pricing Documentation in the form of Code of Conduct with aim to harmonize transfer pricing documentation obligation and requirements in Europe. However, Solilova and Nerudova (2016) and Silberztein (2013) also recommend the introduction of simplified measurements in the area of transfer pricing. Further, in the long run, the European Commission recommends shifting from separate approach, which is represented by arm's length principle, to comprehensive approach in the form of CCCTB, where transfer pricing transactions would have any impact on the group's tax base due to their elimination.

\section{Methodology}

To reach the aim of the paper, firstly the costs of transfer pricing of SMEs (time and costs) were determined through results of a questionnaire, Secondly, the weighted average value of compliance costs for the representative sample were used to define transfer pricing compliance costs for the entire taxpayer category (SMEs) in the Czech Republic. Then the indicator of compliance costs of transfer pricing to corporate tax paid was measured. Finally, the results were compared with current knowledge in the research area.

As was mentioned above, the measurement of compliance costs is difficult. There are two ways how to receive data for the measurement of compliance costs. The first of them is an expert estimation, such as Paying Taxes report, and second one is a questionnaire.

Paying Taxes report has been annually published together with Doing Business report since 2003, which measures the business environment in 189 countries by using a standardised, mid-sized firm and used platform of the World Bank. Paying Taxes indicator measures tax payments, time and total tax rate. For our paper's purpose, mainly for the comparison, there will be used a time indicator, which symbolizes the compliance with three major taxes i.e. VAT (and other consumption taxes), Corporate Income Tax and Labour taxes with social contributions, which are considered as the most time-consuming taxes for businesses across the world. Based on the last report 2014/2015, time indicator of three major taxes for the Czech Republic is 405 hours per year. However, it must be highlighted that the Paying Taxes expert estimation has some disadvantages, such as using a standardized mid-sized firm and therefore inability to determine compliance costs in dependence on size of the entity.

The measurement of compliance costs through the questionnaire was done by a stratified random sampling from the Amadeus database. Firstly, there were selected three groups of enterprises from the Amadeus database: (i) medium sized entities having less than 250 employees with an annual turnover less than EUR 50 million and annual balance sheet total less EUR 43 million, (ii) small entities having less than 50 employees with an annual turnover less than EUR 10 million and 
Solilová, V. - Nerudová, D. - Bohušová, H. - Svoboda, P.: Compliance Costs of Transfer Pricing in Case of SMEs: Czech Case.

annual balance sheet total less EUR 10 million and (iii) micro sized entities having less than 10 employees with an annual turnover less EUR 2 million and annual balance sheet less EUR 2 million. Secondly, those entities have to own a branch or a subsidiary between $25 \%$ and $100 \%$ of capital, for only those SMEs are affected by the transfer pricing issues and are considered as associated companies. Then a stratified random sampling was done for the selection of the final representative sample which was questioned through questionnaire. The questionnaire contains 33 questions covering general transfer pricing issues, compliance costs of transfer pricing and tools for decreasing of those compliance costs. Altogether we received 29 answers from SMEs having tax residence in the Czech Republic (i.e. Czech parent companies having subsidiaries in Europe and Czech subsidiaries having parent company in Europe). The data were collected online through the application GoogleApps.

\section{Results}

\subsection{Evaluation of Paying Taxes report and questionnaire - key figures}

Based on the results of Paying Taxes report, the standardized mid-sized Czech entities spend almost 51 working days per year for preparing, filling and paying of three major taxes (VAT and other consumption taxes, Corporate Income Tax and Labour taxes with social contributions). Further, those entities bore compliance costs of all measured taxes in the amount of $50.4 \%$ of profit before taxation. It is the fifth highest value between EU Member States. Overall, the Czech Republic has worse position in comparison with Europe and Central Asia or OECD high income countries. For more details see table 2 below.

Tab. 2 Summary of „Paying taxes“ indicator for Czech Republic and comparison with Europe and OECD in 2014/2015

\begin{tabular}{llll}
\hline Country & Rank (1-189) & Time (hours per year) & $\begin{array}{l}\text { Total tax rate } \\
(\% \text { of profit })^{1,2}\end{array}$ \\
\hline Czech Republic & 122 & $405.0(28)$ & $50.4(24)$ \\
Europe \& Central Asia &.. & 232.7 & 34.8 \\
OECD high income &.. & 176.6 & 41.2 \\
\hline
\end{tabular}

Source: World Bank, 2016, own processing.

Note: 1) In bracket is mentioned rank achieved in individual category of EU Member States, 2) Represents a share of profit before all taxes for calendar year 2014. 
As regards the survey of compliance costs of transfer pricing in case of SMEs having tax residence in the Czech Republic, we received 29 answers covering $3.4 \%$ of micro entities, $34.5 \%$ of small entities and $62.1 \%$ of medium-sized entities. Further, 55.2 \% represent Czech subsidiaries having parent company in Europe and $44.8 \%$ represent Czech parent companies having subsidiaries in Europe, namely in Czech Republic, Germany, Romania, Hungary and Bulgaria. In addition, those entities are operating mainly in industry NACE C and G $(19.5 \%)$, then in industry NACE M (17.1\%) and in industry NACE H, N, F, J, L, K and S (under $10 \%)^{5}$

In respect of tax consultancy for transfer pricing issue, the survey shows that only $5.7 \%$ of respondents do not use the tax consultant services for transfer pricing issues contrary with almost $38 \%$ of them who are using this kind of services for all matters, regardless of whether it is transfer pricing issue. Further, almost $19 \%$ of responders use them for the preparation of transfer pricing documentation, more than $15 \%$ of them for the consideration of the most suitable transfer pricing method and more than $11 \%$ of them in case of transfer pricing disputes. Moreover, in case of the new obligation to fulfil the Czech equivalent of country-by-country report in tax return, $5 \%$ of responders use tax consultant services for this kind of administrative task.

Other part of survey was focused on the management of transfer pricing issues, compliance costs of this issues and time required for managing of the issues. As is obvious from the table 3 , management of transfer pricing documentation, which also covers the consideration of the most suitable transfer pricing methods, takes from 201 to 300 hours per year at more than $24 \%$ of respondents and more than $20 \%$ of respondents state a spread from 101 to 200 hours per year. In respect of borne costs for managing of transfer pricing documentation, the survey revealed that almost $38 \%$ of respondents spent up to EUR 6,000 per year, almost $35 \%$ of respondents spent up to EUR 9,000 per year contrary with $3.4 \%$ of respondents who spent up to EUR 1,000 or from EUR 9,001 to 12,000 (for more details see table 3 below).

5 Industry NACE C - Manufacturing, F - Construction, G - Wholesale and retail trade; repair of motor vehicles and motorcycles, $\mathrm{H}$ - Transporting and storage, $\mathrm{J}$ - Information and communication, $\mathrm{K}$ - Financial and insurance activities, $\mathrm{L}$ - Real estate activities, $\mathrm{M}$ - Professional, scientific and technical activities, $\mathrm{N}$ - Administrative and support service activities, $\mathrm{S}$ - Other services activities. 
Solilová, V. - Nerudová, D. - Bohušová, H. - Svoboda, P.: Compliance Costs of Transfer Pricing in Case of SMEs: Czech Case.

Tab. 3 Transfer pricing documentation - costs and time

\begin{tabular}{lll}
\hline $\begin{array}{l}\text { 15. Please estimate the time necessary for preparation of transfer pricing } \\
\text { documentation. When doing the estimation, please take into account also } \\
\text { the time necessary for up-date of transfer pricing documentation. }\end{array}$ & No. & $\%$ \\
\hline Up to 100 hours & 3 & 10.3 \\
$101-200$ hours & 6 & 20.7 \\
201 - 300 hours & 7 & 24.1 \\
I am not able to estimate & 11 & 37.9 \\
There is not an obligation to prepare transfer pricing documentation in our & 2 & 6.9 \\
country & \multicolumn{2}{c}{} \\
\hline 16. With respect to the previous question, please estimate the costs related to this issue. \\
\hline Up to EUR 1,000 & 1 & 3.4 \\
EUR 1,001 - 3,000 & 4 & 13.8 \\
EUR 3,001 - 6,000 & 11 & 37.9 \\
EUR 6,001 - 9,000 & 10 & 34.5 \\
EUR 9,001 - 12,000 & 1 & 3.4 \\
There is not an obligation to prepare transfer pricing documentation & 2 & 6.9 \\
\hline
\end{tabular}

Source: Own calculation.

Furthermore, almost $45 \%$ of respondent is not able to estimate time and costs necessary for the consideration of the most suitable transfer pricing method as an important part of transfer pricing documentation. Moreover, nobody from respondents has experience with advance pricing agreement.

As regards to the Czech equivalent of country-by-country report, $50 \%$ of respondents spent from 25 to 56 hours per year with its preparation. Further, this activity is related with costs up to EUR 500 per year at more than $27 \%$ of respondents and between EUR 501 and 1,000 per year at almost $38 \%$ of respondents (for details see table 4 below).

\section{Tab. 4 Country-by-country report - costs and time}

17. If your enterprise

has the obligation to fill

country-by-county

report as an annex of income tax return, please estimate the time necessary for its preparation.

\begin{tabular}{llrllr}
\hline Up to 24 hours per year & 6 & 21.4 & Up to EUR 500 & 8 & 27.6 \\
$25-56$ hours per year & 14 & 50.0 & EUR 501-1,000 & 11 & 37.9 \\
57- 96 hours per year & 2 & 7.1 & EUR 1,001-2,000 & 4 & 14.3 \\
I am not able to estimate & 4 & 14.3 & No obligation to prepare country- & 2 & 6.9 \\
No obligation & 2 & 7.1 & $\begin{array}{l}\text { by-country report } \\
\text { I am not able to estimate }\end{array}$ & 3 & 10.3 \\
\hline
\end{tabular}

Source: Own calculation.
18. With respect to the previous question (country-by-country report), please estimate the costs related to this issue. No. \% 


\subsection{Determination of compliance costs of transfer pricing}

Based on the European Commission and its annual report about SMEs, there should be more than 1.01 mil of SME acting in the Czech Republic. However, this amount covers mainly micro enterprises and relatively small portion of small and medium-sized enterprises. Therefore, the Amadeus database was used for the estimation of amount of SME acting in the Czech Republic, in 2015 together 60,367 SMEs are acting in the Czech Republic.

According to the results of survey, weighted average time needed for transfer pricing issue (i.e. for transfer pricing documentation and country-by-country report) was determined from 211 to 276 hours per year ${ }^{6}$ (almost 27 up to 35 working days) and weighted average of compliance costs was determined from EUR 6,430 to 7,704 per year. Taking into account assumed amount of SMEs acting in the Czech Republic (i.e. 60,367 SMEs), compliance costs of transfer pricing is from EUR 142.3 to 465.1 mil., or from $3.90 \%$ to $12.74 \%$ as a portion of compliance costs to corporate tax collection (for details see table 5 below).

\section{Tab. 5 Determination of compliance costs of transfer pricing}

\begin{tabular}{lllll}
\hline Type & $\begin{array}{l}\text { Compliance } \\
\text { costs for repre- } \\
\text { sentative sample }\end{array}$ & $\begin{array}{l}\text { Compliance costs for whole } \\
\text { group of SMEs }\end{array}$ & $\begin{array}{l}\text { Corporate tax } \\
\text { collection in } \\
\text { 2015 in the } \\
\text { Czech Repub- } \\
\text { lic }^{\mathbf{1}}\end{array}$ & $\begin{array}{l}\text { Compliance } \\
\text { costs of transfer } \\
\text { pricing / corpo- } \\
\text { rate tax collec- } \\
\text { tion (in \%) }\end{array}$ \\
\hline \multirow{2}{*}{ A } & $\begin{array}{l}\text { EUR 6,430 per } \\
\text { year }\end{array}$ & $\begin{array}{l}6,430 * 60,367=\text { EUR 142.3 } \\
\text { mil. }\end{array}$ & $\begin{array}{l}\text { EUR 3,650.7 } \\
\text { mil. }\end{array}$ & 3.90 \\
\cline { 1 - 2 } B & $\begin{array}{l}\text { EUR 7,704 per } \\
\text { year }\end{array}$ & $\begin{array}{l}7,704 * 60,367=\text { EUR 465.1 } \\
\text { mil. }\end{array}$ & 12.74 \\
\hline
\end{tabular}

Source: Own calculation.

Note: A) Calculation based on the median values of individual spread of costs set in questionnaire. B) Calculation based on the highest values of individual spread of costs set in questionnaire. 1) Average exchange rate CZK/EUR for 2015 is CZK 27.283 per 1 EUR. Corporate tax collection for 2015 is CZK 99.6 billion.

In comparison with results of previous studies is obvious, that transfer pricing generates very huge compliance costs of taxation, e.g. more than $50 \%$ of time indicator based on the Paying Taxes report as well as in case of studies Vítek et al. and Pudíl et al. (for details see table below). Moreover, if the highest values of individual spread of costs set in the questionnaire are taken into account, then the compliance costs of transfer pricing represent more than double of compliance costs of corporate taxation, particularly $12.74 \%$ of corporate tax collection. Increased time indicator and compliance costs of transfer pricing in comparison with compliance costs of corporate taxation may be caused by the fact that currently

6 It is determined according to the median and the highest values of individual spread of time set in questionnaire. 
Solilová, V. - Nerudová, D. - Bohušová, H. - Svoboda, P.: Compliance Costs of Transfer Pricing in Case of SMEs: Czech Case.

transfer pricing issue is very actual and tax administrators are more focusing on this area than before. In this respect entities recognize this pressure and they are also more interested in the area of transfer pricing in consequences of higher compliance costs.

Tab. 6 Comparison of compliance costs

\begin{tabular}{llll}
\hline Type & Studies & Time indicator & $\begin{array}{l}\text { Compliance costs } \\
\text { corporate tax } \\
\text { collection (in \%) }\end{array}$ \\
\hline $\begin{array}{l}\text { Transfer } \\
\text { pricing }\end{array}$ & Own study & $211-276$ hours per year & $3.90-12.74$ \\
\hline $\begin{array}{l}\text { Corporate } \\
\text { taxation }\end{array}$ & $\begin{array}{l}\text { Vitek et al. 2008 } \\
\text { Pudil et al. 2004 }\end{array}$ & - & 5.5 \\
\hline $\begin{array}{l}\text { Three } \\
\text { major } \\
\text { taxes }\end{array}$ & $\begin{array}{l}\text { Paying Taxes report } \\
\text { (2016) for }\end{array}$ & 405 hours per year & 5.3 \\
\hline
\end{tabular}

Source: Own processing.

However, it is questioned whether the results of Paying Taxes are undervalued in comparison with our results of time needed pro transfer pricing issues and a fact that Paying Taxes - time indicator covers three major taxes such as VAT, Corporate tax and Labour taxes.

\section{Conclusions}

The aim of this paper was to determine compliance costs of transfer pricing issues in case of SMEs having tax residence in the Czech Republic (i.e. Czech parent companies having subsidiaries in Europe and Czech subsidiaries having a parent company in Europe) based on data collection through questionnaire.

The survey of compliance costs of transfer pricing of SMEs revealed that compliance of transfer pricing requirements needs tax consultancy which increases compliance costs of taxation. Representative sample of SMEs bear costs for managing of transfer pricing issues (mainly in the form of transfer pricing documentation and country-by-country reporting) from EUR 6,430 to 7,704 and spent time for it from 27 to 35 working days. Taking into account assumed amount of SMEs acting in the Czech Republic (i.e. 60,367 SMEs), compliance costs of transfer pricing is determined between EUR 142.3 and 465.1 mil. This amount of costs as a portion of compliance costs to corporate tax collection represents value from $3.90 \%$ to $12.74 \%$. In comparison with last studies on compliance costs of corporate taxation it is twice more.

Based on the conducted research, we think that tax policymakers should carefully design new tax obligation in the area of transfer pricing and should also address the disproportionately high tax compliance burdens faced by SMEs. In this respect, we can recommend an application of some simplified measurements for 
transfer pricing for decreasing compliance costs of transfer pricing, such as simplified transfer pricing documentation, exclusion of micro entities from the transfer pricing requirements or implication of safe harbour ${ }^{7}$ for selected industries and types of transactions (i.e. for loan, royalties, intangibles or others).

\section{References}

Amadeus Database, Bureau Van Dijk.

Bartelsman, E., Beetsma, R., 2000. Why Pay More? Corporate Tax Avoidance through Transfer Pricing in OECD Countries., Tinbergen Institute Discussion Paper No. 00-54/2. Available from: <http://www.rrojasdatabank.info/wir2006/ pricetransfer.pdf >. [31 September 2016].

Buus, T., 2009. Vhodný kalkulační vzorec s ohledem na rozhodování o ceně (transferové ceně) a maximalizaci hodnoty podniku. Český finanční a účetní časopis 2, 33-45. DOI: 10.18267/j.cfuc.27.

Carrol, M., B., 1933. Taxation of Foreign and National Enterprises: Vol. IV, Methods of Allocating Taxable Income. Available from: $<$ http://archive.org/stream/taxationofforeig031922mbp/taxationofforeig031922mb p_djvu.txt>. [28 August 2016].

Chittenden, F., Michaelas, N., Poutziouris, P., 2000. Small Business Taxation: An Agenda for Growth, EDC: Manchester Business School.

Cordova-Novion, C., De Young, C., 2001. The OECD / Public Management Service Multi-Country Business Survey - Benchmarking Regulatory and Administrative Business Environments in Small and Medium Sized Enterprises. In C. Evans, Pope, J., \& Hasseldine, J. (Eds), Tax Compliance Costs: A Festschrift for Cedric Sandford, Prospect, Sydney.

Cressy, R., 2000. Tax, Assistance, Compliance and the Performance of the Smaller Business. Research Report to the Federation of Small Business.

European Commission, 2015. Annual reports on European SMEs 2014/2015. SMEs start hiring again.

European Commission, 2002. Recommendation 2003/361/EC of 6 May 2003.

Evans, C., 2003. Taxing personal capital gains: Operating cost implications. Australian Tax Research Foundation, Sydney.

Green, S., 1994. Compliance Costs and Direct Taxation. The Institute of Chartered Accountants in England and Wales, London.

7 Safe harbour is determined usually as a range of arm's length rate, which are accepted by tax administrators. After that taxpayers may not incur costs and time for the determination of arm's length rate/margin resulted into lower compliance costs of taxation. 
Solilová, V. - Nerudová, D. - Bohušová, H. - Svoboda, P.: Compliance Costs of Transfer Pricing in Case of SMEs: Czech Case.

Hines, J. R., Jr., E. M. Rice, 1994. Fiscal Paradise: Foreign Tax Havens and American Business. Quarterly Journal of Economics 1, 149-182. DOI: 10.3386/w3477.

Huizinga, H., L. Laeven, 2006. International profit shifting within multinationals: a multi-country perspective. European Economy. Economic Papers 260. Available from: 〈http://ec.europa.eu/economy_finance/publications/publication590_en.pdf〉. [3 September 2016].

Keuschnigg, C., Devereux, M., 2013. The Arm's Length Principle and Distortions to Multinational Firm Organization. Journal of International Economics 2, 432440. DOI: 10.1016/j.jinteco.2012.08.007.

KPMG, 1996. Tax Simplification: A Survey of UK Listed Companies. KPMG London.

KPMG, 2006. Administrative Burdens - HMRC Measurement Project. KPMG, London. Available from: <http://webarchive.nationalarchives.gov.uk/201401 09143644/http://www.hmrc.gov.uk/better-regulation/kpmg.htm>. [20 September 2016].

Lohse, T., Riedel, N., 2013. Do Transfer Pricing Laws Limit International Income Shifting? Evidence from European Multinationals. CESifo Working Paper, No. 4404. Available from: <https://fiwi.uni-hohenheim.de/fileadmin/einrichtungen/ fiwi/Mitarbeiter/Paper_2013_09_17.pdf>. [29 August 2016].

Nerudová, D., Bohušová, H., Svoboda, P., Široký, J., 2009. Harmonizace účetních standardů pro malé a střední podniky. Wolters Kluwer, Praha.

Obermair, C., Weninger, P., 2008. Tax Compliance Costs for Companies in an Enlarged European Community. General Report. In Lang et al. (Eds), Tax Compliance Costs for Companies in an Enlarged European Community. Linde, Wien.

OECD, 1995. Transfer Pricing Guidelines for Multinational Enterprises and Tax Administrations. OECD Publication Service, France.

OECD, 2001. Businesses` Views on Red Tape. Administrative and Regulatory Burdens on Small and Medium-sized Enterprises. Organisation for Economic Cooperation and Development, Paris. DOI: 10.1787/9789264193468-en.

OECD, 2010. Transfer Pricing Guidelines for Multinational Enterprises and Tax Administrations. Available from: <http://www.oecd.org/publications/oecdtransfer-pricing-guidelines-for-multinational-enterprises-and-tax-administrations20769717.htm>. [5 September 2016].

Pavel, J., Vítek, L., 2015. Vyvolané náklady daňového systému v ČR. Politická ekonomie 3, 317-330. DOI: 10.18267/j.polek.1005.

Pudil, P., Vybíhal, V., Vítek, L., Pavel, J., et al. 2004. Zdanění a efektivnost. Eurolex Bohemia, Praha. 
Pris, P., Gornnet, S., Meghames, R., 2014. Understanding Risk in the Enterprise: The Key to Transfer Pricing for Today's Business Models. International Transfer Pricing Journal 6, 395-401.

Rojíček, M., 2012. Vliv globalizace na fungování mezinárodního obchodu. Politická Ekonomie 2, 187-207. DOI: 10.18267/j.polek.837.

Sandford, S. C., 1995. Tax Compliance Costs - Measurement and Policy. Fiscal Publications in association with The Institute for Fiscal Studies, Bath.

Shaw, J., Slemrod, J., Whiting, J., 2008. Administration and Compliance. Chapter prepared for the Report of a Commission on Reforming the Tax System for the 21st Century (Mirrlees Review). Institute for Fiscal Studies. Available from: <http://eml.berkeley.edu// saez/course/Shawetal_IFS\%282009\%29.pdf〉.

$[22$ September 2016].

Silberztein, C., 2013. OECD: Transfer Pricing Safe Harbours. International Transfer Pricing Journal 2, 63-68.

Joel Slemrod, J., 2006. The (Compliance) Cost of Taxing Business. Available from: <http://webuser.bus.umich.edu/jslemrod/pdf/cost_of_taxing_business.pdf > . [16 September 2016].

Solilová, V., Nerudová, D., 2016. Návrh bezpečných př́istavů v oblasti převodních cen pro malé a střední podniky. Politická ekonomie 5, 558-571. DOI: 10.18267/j.polek.1075.

Solilová, V., Nerudová, D., 2013. Transfer pricing: general model for tax planning. Ekonomický Časopis 6, 597-617.

Solilová, V., Nerudová, D., 2012. The effects of changes in transfer pricing policy of the business models in 21st century. New Role of Public Finance 2012, 247257. Wolters Kluwer ČR, Praha.

Solilová, V., Steindl, M., 2013. Tax Treaty Policy on Article 9 of the OECD Model Scrutinized. Bulletin for International Taxation 3, 128-136.

Swenson, L. D., 2001. Tax Reforms and Evidence of Transfer Pricing. National Tax Journal 1, 7-25. DOI: 10.17310/ntj.2001.1.01.

Taylor, G., Richardson, G., Lanis, R., 2015. Multinationality, Tax Havens, Intangible Assets, and Transfer Pricing Aggressiveness: An Empirical Analysis. Journal of International Accounting Research 1, 25-57. DOI: 10.2308/jiar-51019.

Vítek, L., Pavel, J. 2008. Analýza nákladů soukromého sektoru vyvolaných daňovým systémem (výzkumná studie). Vysoká škola ekonomická v Praze a Ministerstvo financí ČR, Praha.

Wells, B., Lowell, C., 2014. Tax Base Erosion: Reformation of Section 482's Arm's Length Standard. Florida Tax Review 10, 737-797. DOI: 10.2139/ssrn.2310882. 
Solilová, V. - Nerudová, D. - Bohušová, H. - Svoboda, P.: Compliance Costs of Transfer Pricing in Case of SMEs: Czech Case.

World Bank, 2016. Doing Business 2016: Measuring Regulatory Quality and Efficiency. World Bank, Washington, DC. Available from: <http://www.doingbusiness.org/ /media/GIAWB/Doing\%20Business/Documents/ Annual-Reports/English/DB16-Full-Report.pdf>. [15 September 2016]. 